\title{
Permeability estimation in shale formations on the basis of desorption data and radial gas flow model
}

\begin{abstract}
The paper presents a method for estimating the permeability of the shale rock based on the results of desorption and using a radial flow model in calculations. In this model, the volumetric flow rate is a function of both the pore size distribution (various flow mechanisms) and of the organic matter content. The tests confirmed the validity of the assumptions. Deviations from the correlation between permeability and TOC content, are the result of anomalous water saturation. The permeability estimation method for large sections of the core significantly reduces the fluctuations caused by the presence of local range microfractures.
\end{abstract}

Key words: permeability, shale, desorption.

\section{Estymacja przepuszczalności skał formacji łupkowych na podstawie wyników desorpcji i przy założeniu radialnego modelu przepływu gazu}

\begin{abstract}
Przedstawiono metodę szacowania przepuszczalności skał łupkowych na podstawie wyników desorpcji oraz wykorzystanie jej do obliczeń modelu radialnego. W modelu tym wielkość objętościowego strumienia przepływu będzie funkcją zarówno rozkładu parametrów przestrzeni porowej (różne mechanizmy przepływu), jak i zawartości substancji organicznej. Przeprowadzone badania potwierdziły zasadność przyjętych założeń. Odstępstwa od krzywej korelacyjnej przepuszczalność - zawartość TOC są efektem anomalnych nasyceń wodą. Metoda estymacji przepuszczalności dla dużych odcinków rdzenia w sposób zdecydowany zmniejsza fluktuacje spowodowane obecnością mikroszczelin o lokalnym zasięgu.
\end{abstract}

Słowa kluczowe: przepuszczalność, łupki, desorpcja.

\section{Introduction}

Rock permeability is a key input parameter associated with the characterization of hydrocarbon reservoirs, forecasting production, determination of the boreholes' grid, or designing hydraulic fracturing treatments [15]. This parameter is particularly important in the case of unconventional hydrocarbons reservoirs in shale formations. Although, in the first stage of a shale gas reservoir's life mainly the system of cracks and fractures, that originate due to hydraulic fracturing, determine the inflow to the well, it is the rock matrix permeability that has a crucial impact on long-term reservoir production, and hence on its profitability.

Contrary to conventional reservoir rocks, the mineral composition of shale rocks contains large amounts of clay minerals and that of organic matter, in which a significant porosity exists. Moreover, most of the pores are in the nanometer range $[11,17]$, in which gas can be accumulated as sorbed gas as well as free gas and flow mechanism changes: deviations from Darcy flow and the effect of sorption on permeability in shales are observed.

The Knudsen number $\left(K_{n}\right)$ is the indicator of flow regime in the pore space $[7,8,18]$. The variability analysis of this parameter (Fig. 1) shows that the greatest deviations from Darcy's law occur at low pore pressures and small pore diameters, and therefore they cannot be neglected in the analysis of flow in shale formation.

Permeability to gas is one of the most difficult properties to quantify when characterizing shales, which can range from micro to nano Darcy. There are many methods to determine 
the permeability of shale rocks. The method of permeability measurement on crushed samples using pulse-decay technique (the Gas Research Institute (GRI) method) [6,9] is one of most frequently used methods. However, the crushed permeability method does not take into account effective stress and that measurement is carried out in conditions where $K_{n}>1$. These issues are considered to be the most serious drawbacks of this method which results in significant measurement inaccuracies [9]. Moreover, the equations for obtaining permeabilities assumes Darcy flow and do not account for slip flow, transition flow and diffusion effects. Under reservoir conditions pore pressures and the pore sizes are too large for pure Knudsen flow and rather transition between Knudsen and Poiseuille flows occurs. Therefore, the contribution of diffusion flow to total flow is so important when permeability measurements are conducted under laboratory conditions. Permeability measurements of rock samples, performed both in a steady and non-steady state, allow a more precise simulation of reservoir conditions (thermobaric conditions, $\left.K_{n}<1\right)$. However, these methods require good quality cores, from which it would be possible to prepare plugs $2.54 \mathrm{~cm}$ in diameter and approx. $4 \mathrm{~cm}$ long, which in case of brittle and laminated/fissile rocks is difficult to achieve. Moreover, this is a point-type measurement, and therefore to estimate permeability distribution in the well an appropriate number of measurements is necessary, and hence an appropriate amount of the drill cores.

Taking into account above-mentioned considerations, the question arises of whether we are able to estimate the shale permeability having a limited amount of consolidated drill cores.

When hydrodynamic tests have not been performed in a well, permeability might be estimated based on a canister

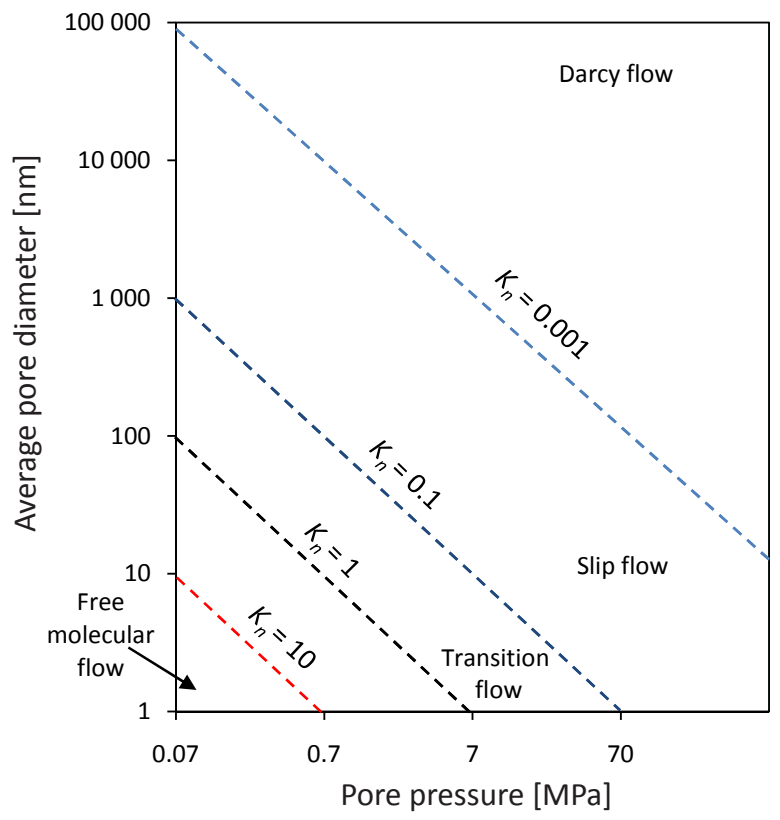

Fig. 1. Flow mechanisms versus pore diameters, pore pressure and Knudsen number [2, 8, 14]

desorption test performed on a drill core. These measurements are the basic empirical method to determine the gas content and composition. Properly planned and carried out desorption tests also allow us to significantly enrich our knowledge of the reservoir and to provide necessary link between laboratory results and production data [3].

This paper analyses the results of drill core desorption tests from Ordovician and Silurian shale formations of the Baltic basin, performed by Company Geokrak Sp. z o.o. The performed tests provided grounds for estimating the permeability of shale formation assuming one-dimensional radial flow model.

\section{Measurement of Desorbed Gas Volume}

Drill cores are often desorbed on site to evaluate the total gas content of target gas shale reservoirs which consists of desorbed gas, lost gas (gas released from the core since the coring start till placing the core in a tight canister), and residual gas (gas released from ground samples of desorbed core at the reservoir temperature). The free gas is determined from the difference between the desorbed and adsorbed gas (based on the Langmuir isotherm) [10]. The desorption data often provides the only information available for quantitative assessment of permeability and diffusivity in shales.

Once cores are retrieved from a well they are immediately put into specially designed canisters at reservoir temperature to desorb gas at nearly constant ambient pressure. The cumulative volume of desorbed gas is measured, by means of a volumeter, at specified time intervals. This kind of procedure guarantees reliable results.

In this study 37 rock samples from the Pomeranian basin have been analysed, including 17 Sylurians' and 10 Ordovicians'. The average TOC content for Sylurian (Wenlock) samples was $0.84 \%$, for Sylurian (Llandovery) $-1.74 \%$ and for Ordovician $-3.25 \%$.

Fig. 2 presents examples of cumulative pore size distribution curves for selected samples. The pore distribution for Lower Sylurian (Fig. 2b) and Ordovician (Fig. 2c) formations shows a much more developed pore space in the range below $100 \mathrm{~nm}$ than samples from Wenlock formation (Fig. 2a).

Gas adsorbs mainly on the surface of the smallest pores, and therefore both the traces of sorption curves and the pore volumes' correlate with the organic matter content (TOC) [13]. 
However, in most of the Shale formations high TOC value means large micropores' share in total porosity, and high rock sorption capacity, in the case of analysed sample such trend was not observed. Relatively low TOC content (up to

a)

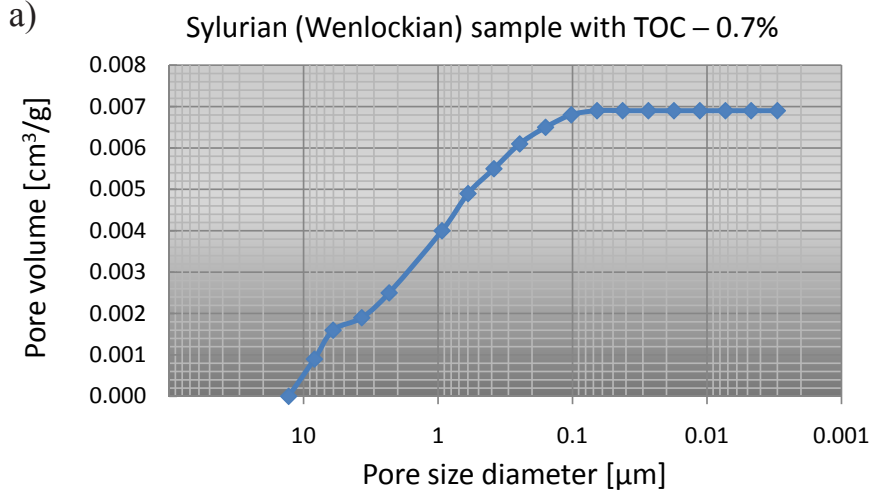

c)

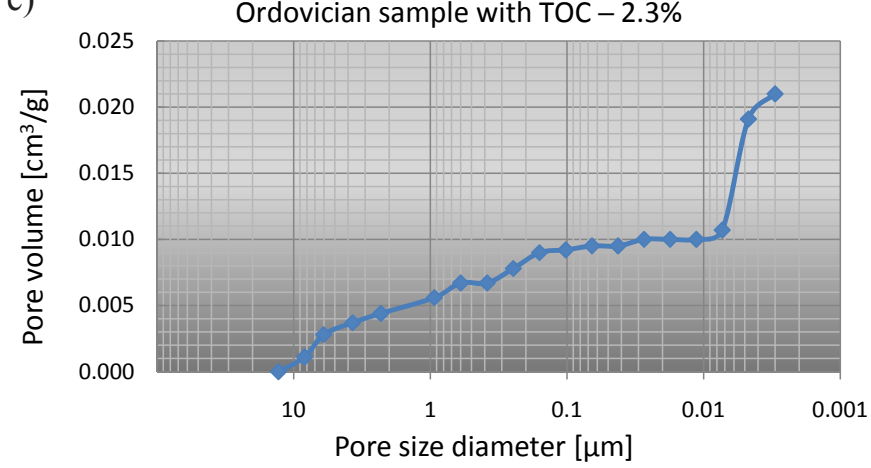

$1 \%$ Fig. 2) does not affect the total porosity. It means that the great part of micropores is in the clays minerals and their composition as well as water saturation will affect the most sorption capacity of Pomeranian shales.

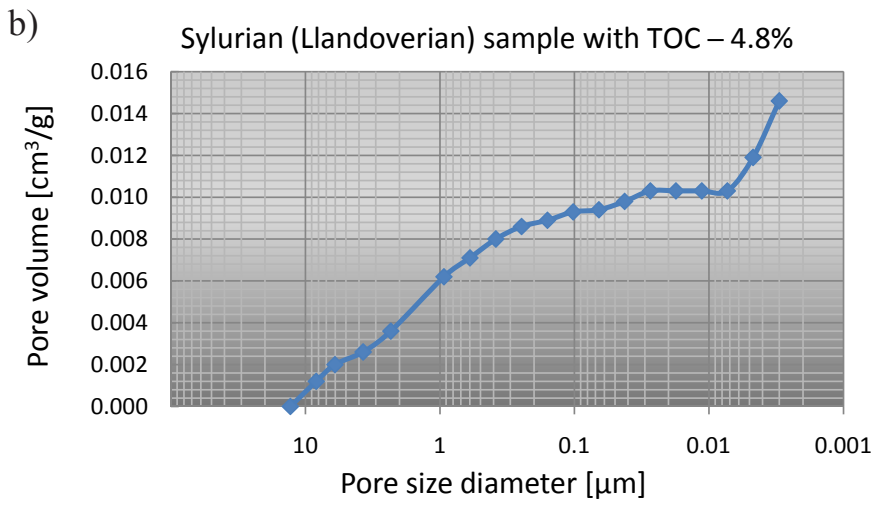

Fig. 2. Examples of cumulative pore size distribution curves for selected samples: a) Wenlockian, b) Llandoverian, c) Ordovician

\section{Permeability estimation of Shale Rocks - Assumptions and Used Models}

Both pore space parameters and the organic matter content and its degree of metamorphosis have a significant impact on the shale rocks permeability. Because of the relatively small average organic matter content in the analysed samples, to estimate permeability a number of simplifications were made, which in the case of samples with higher TOC content can result in underestimation of permeability results $[1,8,16]$.

Figure 3 presents a simplified scheme of gas transport mechanism in shale rock formations. It assumes a flow, caused by a pressure gradient, of free gas from pores existing in the rock matrix to fractures (fracture porosity) and then to the well. It is assumed that diffusion, exists mainly in the smallest pores and because of time factor, has a negligible share in the gas flow stream. The desorption process occurs when the pore pressure is reduced and adsorbed gas molecules can move and diffuse to the pore spaces from the minerals' surface and from the organic matter. Then the desorbed gas becomes a free gas and is subject to the same flow mechanisms as the gas accumulated in the primary porosity of the given rock.
Another simplification exists in the application of a one dimensional radial model, which assumes steady horizontal flow (Fig. 4), then the volumetric stream of gas flow $(Q)$ may be determined from Darcy's equation $[5,20]$ :

$$
Q=\frac{2 \pi k h\left(P^{2}-P_{0}^{2}\right)}{\mu \ln \left(\frac{R}{r}\right)}
$$

where:

$Q$ - volumetric flow rate $\left[\mathrm{m}^{3} \mathrm{~s}^{-1}\right]$,

$k$ - permeability $\left[\mathrm{m}^{2}\right]$,

$h$ - thickness of reservoir rock [m],

$P_{0}-$ pressure on the borehole wall $[\mathrm{Pa}]$,

$P$ - pressure on the deposit contour [Pa],

$\mu$ - gas viscosity $[\mathrm{Pa} \cdot \mathrm{s}]$,

$R$ - radius of the reservoir rock (deposit) contour [m],

$r$ - borehole radius [m].

Darcy's law itself does not contain sufficient information to solve transient flow (i.e. time-dependent). In order to develop a complete governing equation that applies to transient 
problem a mathematical expression of the principle of mass conservation should be derived.

Taking into account, that gas transport in shale rock may be due to either diffusion and/or Darcy's flow and gas desorption data, where the length of the drill core is sufficiently larger than its diameter and its gas is desorbed in relatively small pressure changes, gas transport through the core may be described by the material balance equation:

$$
\frac{\partial p}{\partial t}=\frac{k}{\mu c_{g}\left(\phi+(1-\phi) K_{a}\right)} \cdot \frac{1}{r^{2}}\left(r^{2} \frac{\partial p}{\partial r}\right)
$$

with boundary (BC) and initial (IC) conditions of:

$$
\begin{aligned}
& \mathrm{BC} 1: \frac{\partial p}{\partial r}=0 \text { at } r=0 ; \mathrm{BC} 2 ; p=p_{c} \text { at } r=R_{a} \\
& \text { and IC: } p=p_{0} \text { for } 0 \leq r \leq R_{a} \text { at } t=0
\end{aligned}
$$

where:

$p_{c}$ - pseudo pressure at ambient pressure and reservoir temperature $[\mathrm{Pa}]$,

$p_{0}$ - initial gas pseudo pressure in drill core,

$K$ - apparent transport coefficient $\left[\mathrm{m}^{2} \mathrm{~s}^{-1}\right]$,

$K_{a}$ - partial derivative of adsorbate density with respect to gas density,

$c_{g}$ - gas compressibility $\left[\mathrm{Pa}^{-1}\right]$,

$\phi$ - porosity,

$r$ - displacement [m],

$\rho-$ density of the desorbed gas from core which should remain constant $\left[\mathrm{mol} \mathrm{m}^{-3}\right]$.

The mass fraction $F_{D}$ of cumulative gas desorbed from the drill core relative to total gas to be desorbed with time can theoretically be given as:

$$
F_{D}=1-4 \sum_{n=1}^{\infty} \frac{1}{\xi_{n}^{2}} e^{-K \xi_{n}^{2} t / a^{2}}
$$

where $\xi_{n}$ is $\mathrm{n}^{\text {th }}$ root of Bassel equation.

Theoretically, early time and late time data should give a similar permeability for homogenous reservoir rocks. However, early-time data is likely of poorer quality and does not reflect in the appropriate way heterogeneous dual porosity rocks. Late time data provide more accurate information and enable us to find an approximate solution of equation (3) as:

$$
\ln \left(1-F_{D}\right)=\ln \left(\frac{4}{\xi_{1}^{2}}\right)-\frac{K \xi_{1}^{2}}{R_{a}^{2}} t
$$

where $\xi_{1}$ is $1^{\text {st }}$ root of Bassel function, $j_{0}(\xi)=0$, and is equal to 2.404834. Therefore, if the late-time desorption is plotted versus time, a straight line is obtained, with the slope $s_{1}$ and permeability $k$ can be determined as $[4,12]$ :

$$
k=\frac{R_{a}^{2}\left(\phi+(1-\phi) \mu c_{g} s_{1}\right.}{\xi_{1}^{2}}
$$

To estimate permeability, the total flow rate of desorbed gas was taken as the total volumetric flow rate and permeabilities for individual fragments of the drill core were recalculated. The presented way of indirect permeability estimation, introduces to Darcy's law a correction related to different flow mechanisms in shale rocks (desorption, diffusion, slip flow).

To verify estimated permeabilities based on the available

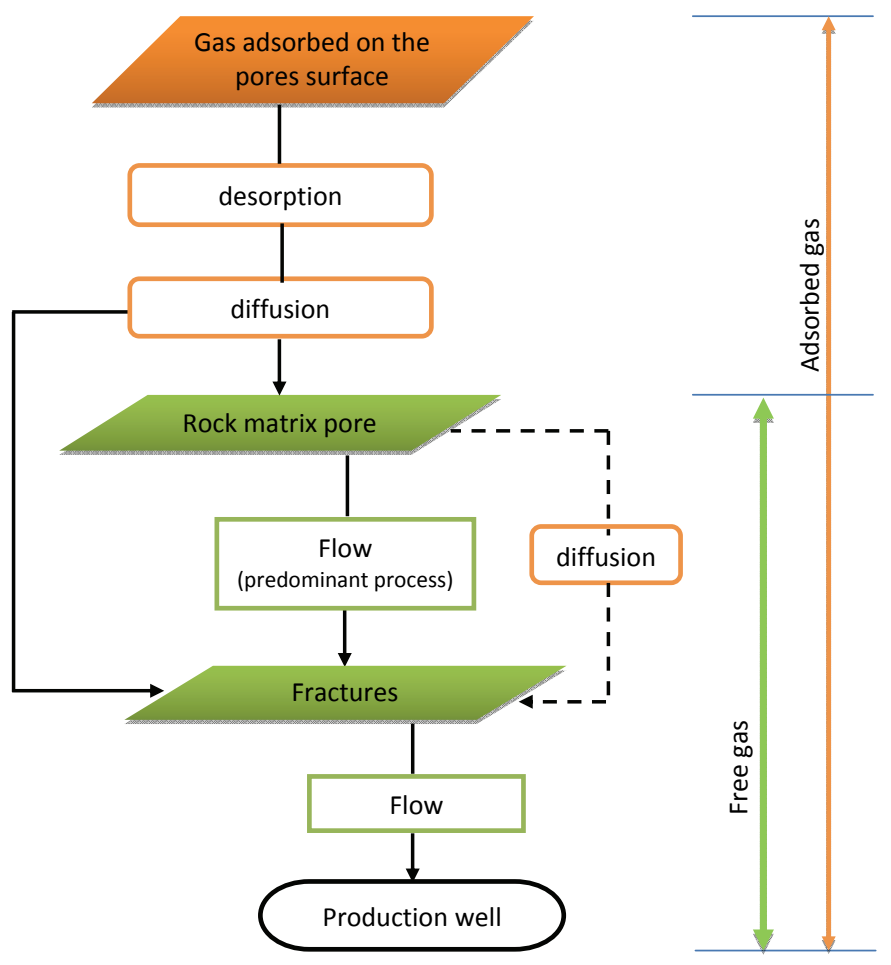

Fig. 3. Gas transport mechanism in shale rocks

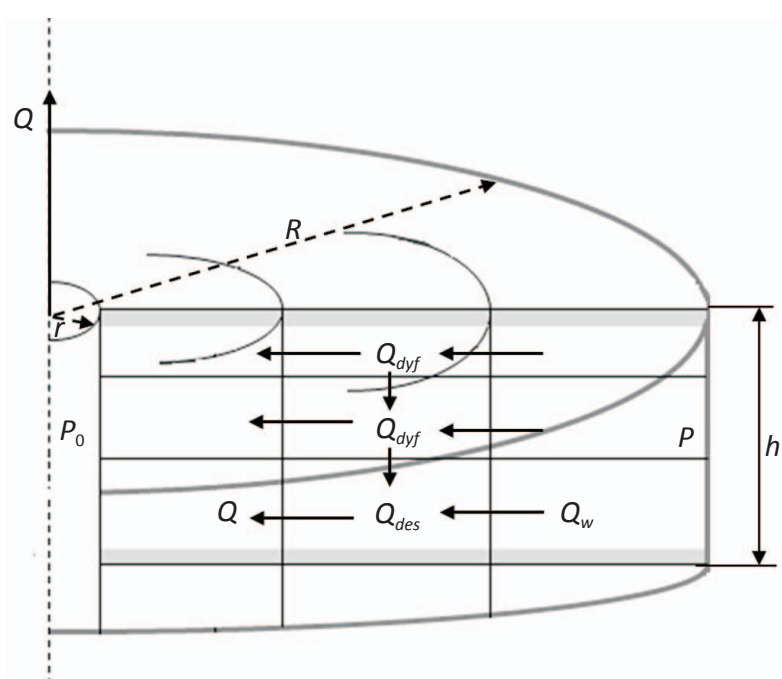

Fig. 4. Scheme of radial filtration towards the borehole: $Q$ - total volumetric flow rate, $Q_{\text {des }}$ - volumetric flow rate of desorbed gas, $Q_{w}$ - volumetric flow rate of free gas, $Q_{d y f}$ - volumetric flow rate of diffused gas; other symbols acc. to formula (1) 
core material (plugs $2.54 \mathrm{~cm}$ in diameter and approx. $4 \mathrm{~cm}$ long) for 7 samples permeability was measured using Pulse-Decay technique on a permeameter (PDP-250 CoreLab ${ }^{\circledR}$ ). The measurement procedure was described in detail in paper [19].

\section{Results and Discussion}

Permeability values for shale rocks, estimated based on data from core desorption tests, range from 0.06 to $4.79 \mu \mathrm{D}$. These values are close to the permeability values for the shales presented in the literature, which vary from a few dozen to a few hundred $\mathrm{nD}$ [7].

The results presented in Fig. 5 show permeability changes with the depth and with the organic matter content. In general, permeability is strongly correlated with the organic matter content, and therefore with the total gas content (Fig. 6). This dependence is indirectly linked to sorption phenomena. It is important to note that desorption being

a) Permeability [mD]

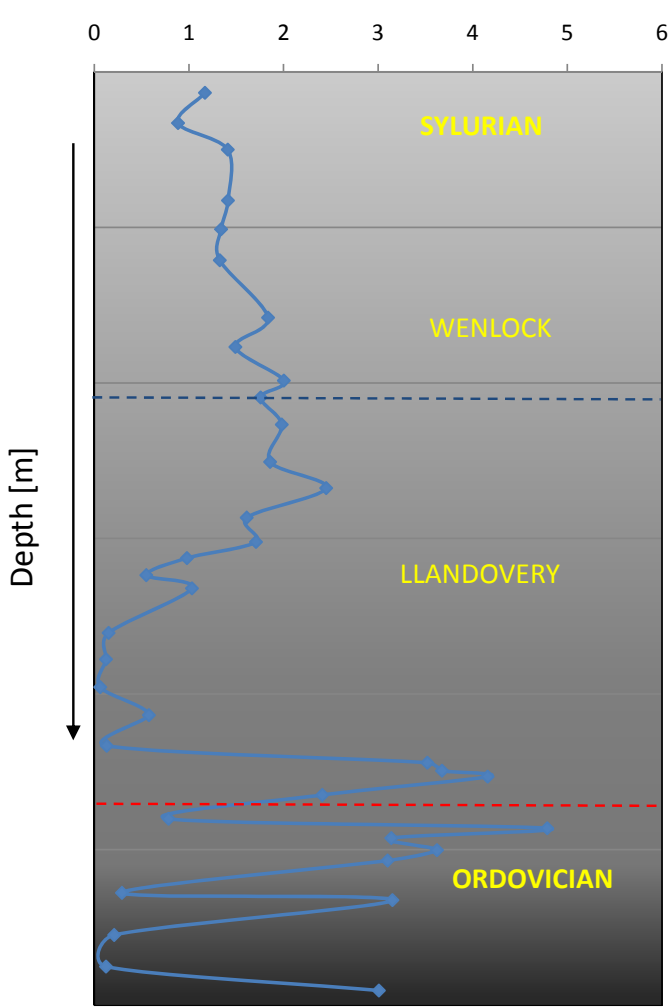

b)
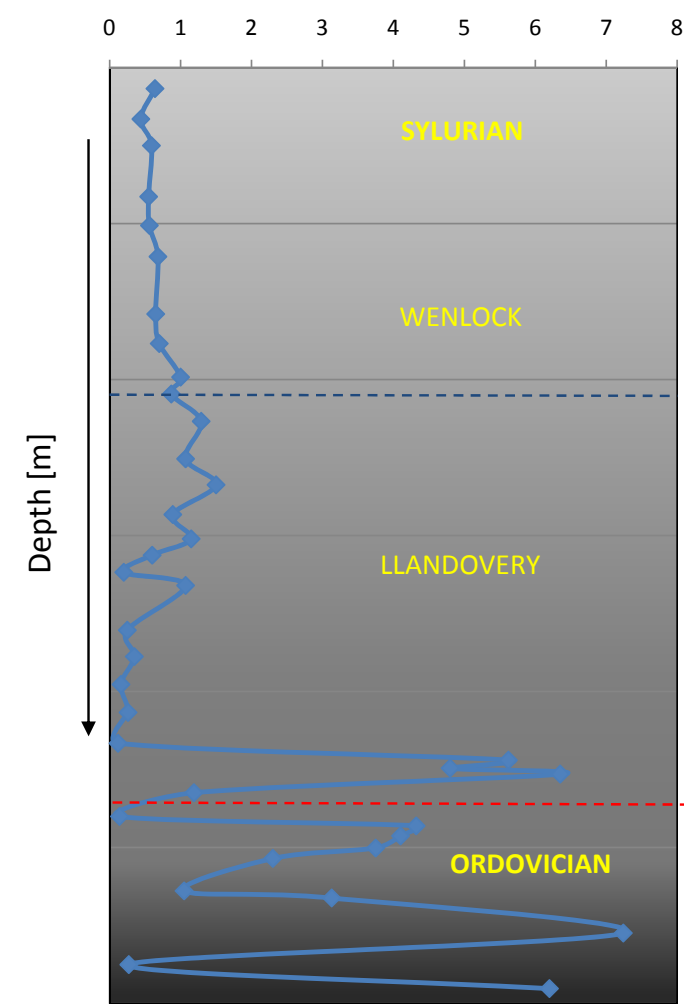

Fig. 5. Profile of a) permeability and b) organic matter content in analysed rocks independent phenomenon has a completely different response to pressure - with declining pressure the contribution of desorbed gas will vary and during exploration will affect the decline trend accordingly. Therefore, production life cycle of shale gas reservoir depends on formation sorption capacity. Deviation from strongly positive TOC and permeability correlation may be noticed for three samples from Ordovician formations, containing 7.24, 1.05 and $4.32 \mathrm{wt} . \%$ of organic matter. This discrepancy results from the specific structure of these rocks characterized by low open porosity, where in the sample containing 7.24 and 1.05 wt.\% of TOC the reservoir water occupies more than $75 \%$ and $98 \%$ of the pore space volume, respectively (Table 1).

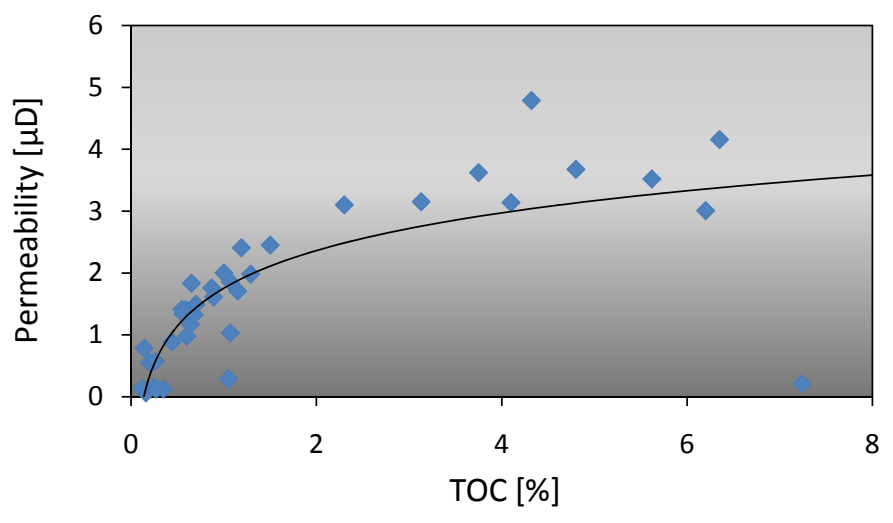

Fig. 6. Correlation between rock matrix permeability of shale formations and organic matter content $\left(R^{2}=0.63\right)$. Numbers 1, 2, 3 refer to samples specified in Table 1

Table 1. Petrophysical parameters of samples differing from the trend

\begin{tabular}{|c|c|c|c|c|c|c|}
\hline Symbol & $\begin{array}{c}\text { TOC } \\
{[\%]}\end{array}$ & $\begin{array}{c}\text { Total porosity } \\
{[\%]}\end{array}$ & $\begin{array}{c}\text { Open porosity } \\
{[\%]}\end{array}$ & $\begin{array}{c}\text { Saturation with water } \\
{[\%]}\end{array}$ & $\begin{array}{c}\text { Total gas content } \\
{\left[\mathrm{m}^{3} / \mathrm{t}\right]}\end{array}$ & $\begin{array}{c}\text { Permeability } \\
{[\mu \mathrm{D}]}\end{array}$ \\
\hline 1 & 7.24 & 1.87 & 1.49 & $>75 \%$ & 0.06 & 0.21 \\
\hline 2 & 4.32 & 8.28 & 3.62 & $8 \%$ & 1.96 & 4.78 \\
\hline 3 & 1.05 & 6.31 & 3.19 & $>98 \%$ & 0.49 & 0.29 \\
\hline
\end{tabular}




\section{Verification of Estimated Permeabilities}

To verify the accuracy of estimated permeability values for samples for which the core material was available, permeability was measured using the pulse decay method. Measured permeability ranged from 0.03 to $0.29 \mu \mathrm{D}$ for samples without microfractures, and from 14.35 to $102.75 \mu \mathrm{D}$ for samples with stated fractures.

Both estimated and measured permeability values for selected samples of shale rocks have values of the same order of magnitude. Differences between the measured and estimated values may be related to the high heterogeneity of shale rocks, and also to the fact that during lab tests reservoir conditions were not maintained (measurements were performed at room temperature).

The issue of appropriate sample preparation for tests is also important. Overestimated values of rock matrix permeability from the range of $0.1 \div 0.01 \mathrm{mD}$ are caused by natural microfractures or induced fractures at the stage of plug preparation (coring, drying) or during the relief of confining stress which occurs when the core is brought to the surface.

In turn, permeability results obtained from a canister desorption may be affected by underestimation of gas volume. Depending on the time required to collect drill cores certain gases may be selectively lost from macroscopic fractures and open pores, and only gas in the micropores may be preserved when the core is sealed in a canister. Therefore, permeability determined from desorption test data may reflect, in the most accurate way the intact matrix. Moreover, for heterogeneous or dual porosity rocks the early pressure change is caused by the penetration of gas into or through the larger pores. Consequently, the early time data may result in overestimation of permeability (characterization on macropores) which may be more significant for adsorptive rocks where the majority of the gas is stored in the micropores.

The obtained results show the decisive influence of microfractures on the permeability of plug samples. For large core sections and for the adopted method of permeability estimation this effect is negligible. If the fractures are natural, their low density, small width and small range also affect the estimation. This effect is moderate and provide additional information about the possibilities of gas transport through such rocks.

The permeability estimated from desorption data is averaged for large, full-dimension drilling core, and therefore the obtained values are a rough parameters estimation of specific separation. It allows us to relate these data more easily to well tests and upscale the results from the laboratory to reservoir scale. In turn, the studies performed on plug type samples allow the separation of the variability scale of studied rocks, estimating permeability minima and maxima, and characterising various types of pore space.

\section{Summary}

This paper presents a method for shale rock permeability estimation based on desorption studies and assuming a radial model of gas inflow. This approach enables the estimation of permeability at reservoir conditions (pressure, temperature), and also enable to upscale the results, being a link between point-type laboratory tests, well tests and reservoir data.

The results of shale rocks permeability, estimated based on data from desorption studies, range from 0.06 to $4.79 \mu \mathrm{D}$. The presented relationships confirm strong correlations between matrix permeability and organic matter content, and hence the total gas content.

Comparing results obtained from calculations using a radial model and values obtained from measurements on plug type samples, it is possible to state:

- main advantage of permeability determined from on-site desorption tests over other methods is that the gas involved in the test is real natural gas that occurs in the reservoir, instead of helium, nitrogen or pure methane,

- the results of measurement on small plug type samples are dominated by the existence of microfractures. The assessment of whether the fracture is natural or induced during the process of sample preparation is the basic difficulty,

- plug type samples without fractures will be dominated in consolidated rocks, which will result in lower values of permeability for such rocks than the estimation calculated for a large drilling core section,

- an additional effect of permeability estimations using radial flow model is marginalisation of microfractures' (of a $1 \mathrm{~cm}-\mathrm{a}$ few $\mathrm{cm}$ range) influence on the final result, - however, permeability determined from desorption test data may reflect, in the most accurate way to intact matrix, proper estimation of lost gas may allow to obtain adequate estimation of dual porosity system.

Summing up, calculations using the radial model allow the estimation of average permeability values for a specific zone. In turn, studies on small cores allow the measurement of the variability scale and the separation of characteristic types of pore space. 
Please cite as: Nafta-Gaz 2015, no. 11, pp. 833-839, DOI: 10.18668/NG2015.11.04

Article contributed to the Editor 31.08.2015. Approved for printing on 15.10.2015.

The article is the result of research conducted in connection with the project: The methodology for determining sweet spots on the basis of geochemical, petrophysical, geomechanical properties based on the correlation of laboratory test results with geophysical measurements and 3D generating model, co-funded by the National Centre for Research and Development as part of the programme BLUE GAS - POLISH SHALE GAS. Contract No. BG1/MWSSSG/13.

\section{Literature}

[1] Ambrose R. J., Hartman R. C., Diaz-Campos M., Akkutlu I. Y., Sondergeld C. H.: New Pore-scale Considerations for Shale Gas in Place Calculations. SPE-131772, paper presented at the Unconventional Gas Conference, SPE, Pittsburgh 23-25 February 2010.

[2] Bodi T.: Gas flow in the nano size pore channels of tight and nonconventional gas storage formations. Geoscience and Engineering 2012, vol. 1, no. 1, pp. 49-63.

[3] Cui A., Nassichuk B.: The role of wellsite canister Core desorption in characterizing unconventional dry and liquid rich shale gas reservoirs. An indispensable link from laboratory test to field production, GeoConvention 2015, New Horizons, Calgary, Kanada 4-8 May 2015.

[4] Cui X., Bustim A.M., Bustin R.M.: Measurements of gas permeability and diffusivity of tight reservoir rocks: different approaches and their applicatios. Geofluids 2009, vol. 9, pp. 208-223

[5] Dake L. P.: Fundamentals of Reservoir Engineering. Elsevier Science Publishers B.V., Amsterdam 1978, ISBN 0-44441830-X.

[6] Guidry F. K., Luffel D. L., Curtis J. B.: Development of Laboratory and Petrophysical Techniques for evaluating Shale Reservoirs. Gas Research Institute Report 1996, GRI-5/0496.

[7] Javadpour F., Fisher D., Unsworth M.: Nanoscale gas flow in shale gas sediments. Journal of Canadian Petroleum Technology 2007, vol. 46, issue 10, pp. 55-61.

[8] Javadpour F.: Nanopores and Apparent Permeability of Gas Flow in Mudrocks (Shales and Siltstone). Journal of Canadian Petroleum Technology 2009, vol. 48, issue 8, pp. 16-21.

[9] Luffel D. L., Hopkins C. W., Holditch S. A., Shettler P. D.: Matrix permeability measurments of gas productive shales. SPE Annual Technical Conference and Exibition, Houston 3-6 October 1993, SPE 26633.

[10] Mijanović E., Jablonski S.: Koncowy raport desorpcyjny. Archiwum PGNiG S.A., kwiecień 2013.

[11] Passey Q. R., Bohacs K. M., Esch W. L., Klimentidis R., Sinha S.: From oil-prone source rock to gas producing-shale reservoir - geologic and petrophysical characterization of unconventional shale-gas reservoir. SPE International Oil and Gas Conference and Exhibition, Beijing 8-10 June, SPE 131350.

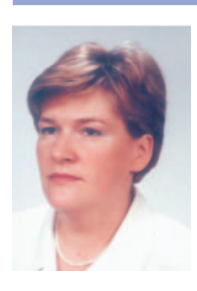

Lidia DUDEK M.Sc. Eng.

Senior Technical Research Specialist

Department of Geology and Geochemistry

Oil and Gas Institute - National Research Institute

ul. Lubicz 25 A

31-503 Kraków

E-mail:dudekl@inig.pl
[12] Rezaee R.: Fundamentals of Gas Shale Reservoirs. John Wiley \& Sons Inc. Hoboken, NJ, USA 2015, ISBN 978-1118-64579-6.

[13] Ross D., Bustin R. M.: The importance of shale composition and pore structure upon gas storage potential of shale gas reservoirs. Marine and Petroleum Geology 2009, 26, pp. 916-927.

[14] Roy S., Raju R., Chuang H. F., Cruden B. A., Meyyappan M.: Modeling gas flow through microchannels and nanopores. Journal of Applied Physics 2003, vol. 93, no. 8, pp. 4870-4879.

[15] Sinha S., Braun E. M., Determan M. D., Passey Q. R., Leonardi S. A., Boros J. A., Wood A. C., Zirkle T., Kudva R. A.: Steady-state permeability measurments on Intact Shale Samples at reservoir Conditions - Effect of stress, temperature, pressure and type of gas. SPE Middle East Oil and Gas Show and Conference, Manama, Bahrain 10-13 March 2013, SPE 164263.

[16] Sondergeld C. H., Ambrose R. J., Rai C. S., Moncrieff J.: Micro-Structural Studies of Gas Shales. Paper presented at the Unconventional Gas Conference, SPE, Pittsburgh 23-25 February 2010, SPE-131771.

[17] Such P., Dudek L., Mroczkowska-Szerszen M., Cicha-Szot R.: Wplyw warunkow zlozowych na parametry filtracyjne skal lupkowych. Nafta-Gaz 2015, no. 11, pp. 827-832.

[18] Such P.: Przeplywy gazu przez nanopory - proba oceny. Nafta-Gaz 2014 no. 10, pp. 671-675.

[19] Such P.: Przestrzen porowa skal lupkowych. Nafta-Gaz 2012, no. 9 , pp. 561-565.

[20] Szott W., Golabek A.: Symulacje eksploatacji zloz gazu ziemnego w formacjach lupkowych (shale gas). Nafta-Gaz 2012, no. 12 , pp. 923-936.

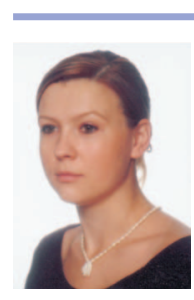

Renata CICHA-SZOT M.Sc. Eng. Junior Scientist Department of Petroleum Engineering Oil and Gas Institute - National Research Institute ul. Lubicz 25 A 31-503 Kraków E-mail: cicha@inig.pl

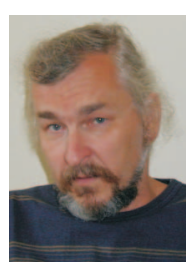

Prof. dr hab. Piotr Such

Assoc. Professor

Deputy Director

Exploration of Hydrocarbons

Oil and Gas Institute - National Research Institute

ul. Lubicz 25 A, 31-503 Kraków

E-mail: piotr.such@inig.pl 